\title{
Nitrogen and Energy Budgets of Free-roaming Cattle
}

\author{
R.L. SENFT, M.A. STILLWELL, AND L.R. RITTENHOUSE
}

\begin{abstract}
Energy and nitrogen ( $N$ ) budgets of free-roaming yearling heifers were quantified. Energy and $\mathbf{N}$ retention were estimated from liveweight gains. Intake and excretion of $N$ and energy were measured directly. Dry matter intake per unit metabolic body weight $\left(\mathrm{MBW}=\mathrm{BW}_{\mathrm{kg}}{ }^{.75}\right.$ ) varied seasonally, peaking in late growing season. Fecal dry matter output, which was related to dry matter intake, also peaked late in the growing season. Urine volume, however, peaked early in the growing season. Urinary $\mathrm{N}$ excretion per MBW was correlated with dietary $N$ concentration $(r=.79)$. Fecal $\mathbf{N}$ excretion per $M B W$ was relatively constant while fecal $N$ concentration varied. Partitioning of $\mathbf{N}$ losses between feces and urine varied seasonally, with $54 \%$ excreted in urine during the growing season (April through October) and $45 \%$ in urine during the dormant season (November through March). On a year-round basis, $8 \%$ of ingested $\mathrm{N}$ was incorporated into body tissue. Fecal energy excretion trend followed that of gross energy intake. Digestible energy intake per MBW was relatively high throughout the growing season and steadily declined after onset of the dormant season. Urinary energy output was closely related to urinary $N$ output and peaked early in the growing season. Metabolizable energy (ME) followed dynamics similar to those of digestible energy. Net energy for liveweight gain accounted for about $8 \%$ of gross energy intake on a year-round basis. ME and crude protein intake were above maintenance requirements during the growing season, but were inadequate during the dormant season. $M E$ intake apparently limited growth early in the growing season; protein intake was limiting late in the growing season.
\end{abstract}

Key Words: cattle, nitrogen, energy, shortgrass

\footnotetext{
At the time of this research, the authors were graduate students and professor Range Science Department, Colorado State University, Fort Collins 80523 . Research was supported in part by National Science Foundation grant DEB-7906009 and by the Colorado State University Experiment Station. We thank the Central Plains Experimental Range for their cooperation. Special thanks to V. Jamison, D. Hansen, and R. Souther for assistance in the field and laboratory.

Senft currently is research associate, USDA-ARS, South Central Family Farm Research Center, Booneville, Arkansas 72927.

Stillwell's present address is Jefferson County Extension Office, 530 D St, Madras, Ore. 97741 .

Manuscript accepted 30 March 1987.
}

Consumption of energy and nutrients by range cattle depends upon forage availability, nutrient content, and gastrointestinal fill (Van Soest 1982). Many of these controls are subject to seasonal variation and may limit forage intake and livestock gains at different times. The primary objective of this research was to quantify seasonal trends in $\mathbf{N}$ and energy consumption, excretion in urine and feces, and growth in cattle grazing a shortgrass range. A secondary objective was to determine whether energy or $\mathrm{N}$ limited cattle growth.

\section{Methods}

\section{The Study Site}

Research was conducted on the USDA-ARS Central Plains Experimental Range (CPER) northeast of Fort Collins, Colorado, on a 125-ha pasture. The climate at CPER is semiarid with an average annual precipitation of $310 \mathrm{~mm}$. Normally, 70 to $80 \%$ fâlls during the growing season, with peak monthly precipitation occurring in May. The vegetation is shortgrass steppe, dominated by blue grama [Bouteloua gracilis (H.B.K.) Griffiths] and buffalo grass [Buchloe dactyloides (Nutt.) Engelm] and is described in detail by Senft et al. (1985). The pasture is normally stocked with 6 to 12 yearling heifers on a year-round basis. During the study the pasture was grazed by 8 yearling heifers.

\section{Excretion of Nitrogen and Energy}

Four yearling heifers were catheterized and fitted with urine and fecal collection bags (Stillwell et al. 1983) for monthly 8-day collection periods from May through November 1981 and in January and March 1982. Fecal bags were changed and urine collection bags were drained twice daily. Feces were thoroughly mixed and subsampled for determination of dry matter, $N$, and energy. Fecal samples were dried at $55^{\circ} \mathrm{C}$ for $\mathbf{4 8}$ hours and ground to pass a $1-\mathrm{mm}$ screen. Samples were analyzed for $\mathrm{N}$ by a modified $\mathrm{Kjeldah}$ technique and for energy by combustion in a bomb calorimeter.

Urea was stabilized by daily additions of $10 \mathrm{ml}$ of $10 \mathrm{ppm}$ phenylmercuric acetate to each urine collection device. Urine samples were refrigerated at $4^{\circ} \mathrm{C}$ after collection and were ana- 
lyzed for Kjeldahl $\mathbf{N}$ and urea by a modified blood urea method (Stillwell and Woodmansee 1981). Energy content of freeze-dried urine was determined in a bomb calorimeter.

Total daily $\mathbf{N}$ and energy excretion were calculated as the products of daily excretion volume and $\mathbf{N}$ or energy concentration. Average excretion rates (volume/time) were estimated for each trial by regression of cumulative excretion volume against cumulative time (days). Slope of the regression equation was a least squares estimate of excretion rate (Johnson et al. 1982).

\section{Consumption of Forage Nitrogen and Energy}

Diet samples were collected from 6 esophageally fistulated yearling heifers tethered on individual plant communities (Senft et al. 1984). Diet samples were dried at $55^{\circ} \mathrm{C}$ for a minimum of 48 hours and ground to pass a 1-mm screen. Ground samples were combined to form pasture diets by compositing community-level samples according to time spent in each community (Senft et al. 1985). One composite pasture diet was constructed for each month of the study. Ground fecal samples were composited across time of day to form a single daily sample for each animal.

Dry matter intake (DMI) was estimated from:

$$
\mathrm{DMI}=\mathrm{E} /(\mathbf{1}-\mathrm{D})
$$

where $\mathrm{E}$ was fecal dry matter excretion $(\mathrm{kg} /$ day) and $\mathrm{D}$ was digestibility of the forage. Digestibility was estimated from:

$$
\mathrm{D}=1-(\text { forage BIDM } / \text { fecal BIDM })
$$

where BIDM was the concentration of biologically indigestible dry matter. BIDM of forage and feces was determined by subjecting samples to an 8-day in vitro digestion followed by a 24-hour acid pepsin post-digestion treatment (modified from Tilley and Terry 1963). The residue was assumed to be biologically indigestible material. DMI was partitioned between forage and supplement using the technique of Rittenhouse et al. (1970), replacing lignin with BIDM.

Experimental animals were individually fed $1,070 \mathrm{~g}$ of $32 \%$ protein supplement 3 times per week during December through March. This level of supplemental feeding was calculated to hold heifers at maintenance (NRC 1984). Fistulated cattle were fed a similar supplement with additional grain (corn, oats, and sorghum) between winter sampling periods.

Intakes of $\mathbf{N}$ and energy were calculated as the products of forage DMI times $\mathbf{N}$ or energy content of the forage plus the products of supplement DMI times supplement $\mathbf{N}$ or energy content.

\section{Nitrogen and Energy Budgets}

Ingested $\mathbf{N}$ was partitioned among feces, urine, and growth. Daily N excretion was calculated directly from measurements on a metabolic body weight $\left(\mathrm{MBW}=\mathrm{BW}_{\mathrm{kg}}{ }^{.76}\right)$ basis. Retention in body tissues was estimated by the method of Dean et al. (1976), where new tissue in growing animals was assumed to be $17 \%$ protein by weight and the ratio of protein $\mathrm{N}$ was assumed to be 6.25 . Average daily liveweight gains were calculated by:

$$
L W G_{t}=\frac{B W_{t+1}-B W_{t-1}}{T}
$$

where $\mathrm{BW}_{\mathrm{t}-1}$ and $\mathrm{BW}_{\mathrm{t}+1}$ were mean liveweights $(\mathrm{g})$ in the previous and following trials and $T$ was the number of intervening days. For comparison, $\mathrm{N}$ retention was also estimated by subtracting urinary and fecal losses from $\mathbf{N}$ intake.

Digestible energy (DE) was calculated as the difference between gross energy intake and fecal energy excretion. Metabolizable energy (ME) was estimated as the difference between DE and urinary energy excretion. Because losses due to gaseous digestion products were not measured, ME estimates were generally higher than if calculated by a standard formula (NRC 1984):

$$
\mathrm{ME}=\mathrm{DE} \times .82
$$

Energy retention (NE gain) was estimated from liveweight gains using:

$$
\mathrm{NE}_{\text {enin }}=0.0686 \mathrm{BW}^{.75} \mathrm{LWG}^{1.119}
$$

(NRC 1984). Energy retention was estimated from liveweight gain because of accumulated error in measurements and because estimates of important energy losses, notably gaseous digestion products and heat increment, were not available.

Was energy or $\mathrm{N}$ intake more limiting to cattle growth on shortgrass steppe? To test nutritional limitation, the relationship between LWG and relative nutrient intake was examined. LWG was converted to relative values to permit comparison of responses across time and body sizes:

$$
\mathrm{RLWG}_{\mathrm{t}}=\frac{\mathrm{LWG}_{\mathrm{t}}}{\mathrm{BW}_{\mathrm{t}}} \times 100 \%
$$

Since energy and $\mathrm{N}$ are measured in incommensurable units, nutrient intake values must be transformed to dimensionless values before comparisons can be made. Relative crude protein intake ( $R C P I)$ and relative $M E$ intake (RMEI) were calculated as ratios of absolute intake per head to maintenance requirement for respective nut rients (NRC 1984). If the concept of limiting nutrients was a

\begin{tabular}{|c|c|c|c|c|c|c|}
\hline \multirow[b]{2}{*}{ Month } & \multicolumn{2}{|c|}{ Dry matter intake } & \multirow{2}{*}{$\begin{array}{c}\text { Digestibility } \\
(\%)\end{array}$} & \multirow{2}{*}{$\begin{array}{c}\text { Fecal dry matter } \\
\left(\mathrm{g} D \mathrm{DM} \bullet \mathrm{B} \mathrm{W}_{\mathrm{kg}}-.7 \text { day }-1\right)\end{array}$} & \multirow{2}{*}{$\begin{array}{c}\text { Urine volume } \\
\left.\mathrm{ml} \cdot \mathrm{BW}_{\mathrm{kg}}^{-.75} \cdot \text { day-1 }\right)\end{array}$} & \multirow{2}{*}{$\begin{array}{c}\text { Body } \\
\text { weight (kg) }\end{array}$} \\
\hline & g DM・BW $W_{k f} \cdot .7$ day -1$)$ & $(\% \mathrm{BW})$ & & & & \\
\hline $\begin{array}{l}\text { May } \\
\text { June } \\
\text { July } \\
\text { August } \\
\text { September } \\
\text { October } \\
\text { November } \\
\text { January } \\
\text { March }\end{array}$ & $\begin{array}{r}73.4 \pm 8.1^{*} \\
97.1 \pm 16.1 \\
93.7 \pm 14.0 \\
108.8 \pm 3.2 \\
117.7 \pm 4.8 \\
120.3 \pm 11.3 \\
102.7 \pm 6.1 \\
73.9 \pm 3.2 \\
85.3 \pm 2.7\end{array}$ & $\begin{array}{l}1.86 \\
2.44 \\
2.28 \\
2.63 \\
2.88 \\
2.82 \\
2.42 \\
1.73 \\
2.02\end{array}$ & $\begin{array}{l}57 \pm 1 \\
67 \pm 1 \\
62 \pm 1 \\
55 \pm 1 \\
51 \pm 1 \\
52 \pm 1 \\
49 \pm 1 \\
46 \pm 1 \\
42 \pm 2\end{array}$ & $\begin{array}{l}31.4 \pm 2.9 \\
31.8 \pm 5.6 \\
35.9 \pm 6.0 \\
48.5 \pm 1.3 \\
58.3 \pm 1.4 \\
57.5 \pm 5.4 \\
52.5 \pm 2.5 \\
38.5 \pm 2.4 \\
47.8 \pm 1.1\end{array}$ & $\begin{array}{r}71 \pm 16 \\
122 \pm 20 \\
101 \pm 40 \\
105 \pm 59 \\
88 \pm 22 \\
37 \pm 14 \\
26 \pm 9 \\
21 \pm 4 \\
19 \pm 1\end{array}$ & $\begin{array}{l}245 \\
252 \\
287 \\
292 \\
291 \\
331 \\
326 \\
323 \\
317\end{array}$ \\
\hline
\end{tabular}
valid description of cattle production response, then the nutrient which was consumed in lesser relative amounts controlled growth. Correlations were examined between RLWG and RMEI, RCPI and intake of the nutrient with the lesser relative intake ratio.

Table 1. Dry matter intake, diet digestiblity, and urine and fecal excretion of free grazing heifers.

"Mean 土 standard deviation 
Table 2. Partitioning of nitrogen in free grasing heifers $\left(\mathrm{N} \bullet \mathrm{BW}_{\mathrm{kg}}{ }^{-.73} \bullet \mathrm{day}^{-1}\right)$.

\begin{tabular}{|c|c|c|c|c|c|c|c|}
\hline \multirow[b]{2}{*}{ Month } & \multirow[b]{2}{*}{ Total N Intake } & \multirow[b]{2}{*}{ Fecal $\mathrm{N}$ excretion } & \multicolumn{3}{|c|}{ Urinary $\mathbf{N}$ excretion } & \multicolumn{2}{|c|}{ N balance } \\
\hline & & & Total N & Urea-N & $\begin{array}{l}\text { Urea-N as \% of } \\
\text { total urinary } \mathrm{N}\end{array}$ & $\begin{array}{l}\text { Difference } \\
\text { method }^{b}\end{array}$ & $\begin{array}{c}\text { LWG } \\
\operatorname{method}^{c}\end{array}$ \\
\hline$\overline{\text { May }}$ & $1.44 \pm 0.16^{2}$ & $0.63 \pm 0.03$ & $0.9 \pm 0.2$ & $0.5 \pm 0.1$ & $63 \pm 2$ & -0.09 & 0.27 \\
\hline June & $2.20 \pm 0.36$ & $0.65 \pm 0.12$ & $1.3 \pm 0.1$ & $0.8 \pm 0.1$ & $67 \pm 3$ & 0.25 & 0.36 \\
\hline July & $1.39 \pm 0.21$ & $0.59 \pm 0.12$ & $0.9 \pm 0.1$ & $0.4 \pm 0.1$ & $48 \pm 5$ & -0.10 & 0.19 \\
\hline August & $1.58 \pm 0.05$ & $0.76 \pm 0.01$ & $0.8 \pm 0.1$ & $0.5 \pm 0.1$ & $55 \pm 7$ & 0.02 & 0.02 \\
\hline September & $1.53 \pm 0.06$ & $0.79 \pm 0.03$ & $0.8 \pm 0.1$ & $0.5 \pm 0.4$ & $58 \pm 4$ & -0.06 & 0.26 \\
\hline October & $1.25 \pm 0.12$ & $0.84 \pm 0.04$ & $0.4 \pm 0.2$ & $0.2 \pm 0.1$ & $37 \pm 10$ & 0.01 & 0.15 \\
\hline November & $0.94 \pm 0.06$ & $0.65 \pm 0.04$ & $0.3 \pm 0.1$ & $0.1 \pm 0.1$ & $38 \pm 8$ & -0.01 & 0.06 \\
\hline January & $0.88 \pm 0.04$ & $0.55 \pm 0.05$ & $0.3 \pm 0.5$ & $0.1 \pm 0.1$ & $34 \pm 5$ & 0.03 & -0.08 \\
\hline March & $0.95 \pm 0.03$ & $0.74 \pm 0.08$ & $0.3 \pm 0.1$ & $0.1 \pm 0.1$ & $30 \pm 5$ & -0.09 & -0.05 \\
\hline
\end{tabular}

-Mean \pm standard deviation

$\mathrm{N}$ balance $=\mathrm{N}$ intake - fecal $\mathrm{N}$ - urinary $\mathrm{N}$

$\mathrm{N}$ balance $=(0.17 \times$ liveweight gain $) / 6.25$

Table 3. Partitioning of energy in free grazing helfers (keal $\left.\bullet \mathrm{BW}_{\mathrm{kg}}^{-.75} \bullet \mathrm{day}^{-1}\right)$.

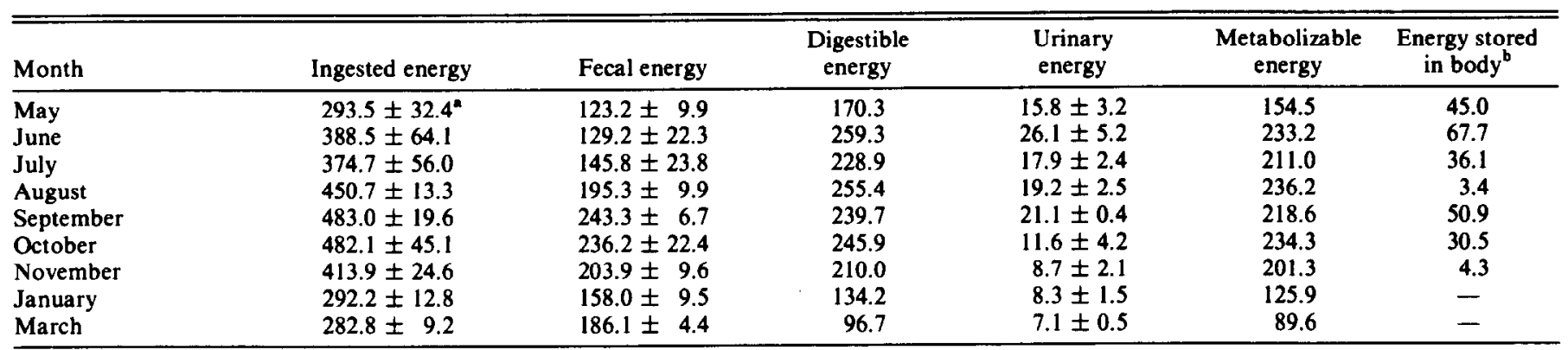

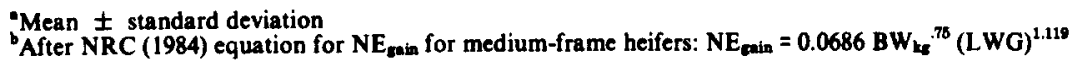

\section{Results and Discussion}

\section{Intake and Excretion}

Dry matter intake varied seasonally (Table 1 ). The highest rates of DMI were measured in the latter part of the growing season after forage digestibility had peaked. Our measured intake levels were between 1.7 to $2.9 \%$ of body weight, which was well within the range reported by others for free-ranging cattle (Cordova et al. 1978). Low DMI in May and June as compared to September and October may have indicated control of DMI by physiological factors rather than by rumen fill (Van Soest 1982). Depressed DMI in January may have been a result of low forage digestibility, low forage availability, or climatic stress (Senft and Rittenhouse 1985).

Urine excretion per MBW was variable among animals and across months (Table 1). Variability among animals may have been due to individual differences in water intake and(or) physiology. Fecal excretion per MBW was highest in September; seasonal trends were related to trends in forage intake and digestibility.

\section{Nitrogen and Budget of Range Cattle}

Monthly $\mathbf{N}$ budgets for free-grazing heifers are shown in Table 2 . Nitrogen intake per MBW was greatest in June when forage $\mathbf{N}$ concentration and DM digestibility were highest and decreased as forage matured. Nitrogen intake was above maintenance requirement of growing heifers (NRC 1984) until November. Submaintenance $\mathrm{N}$ intake continued through March.

Urinary $\mathbf{N}$ and urea-N excretion was highest in June and lowest in November, January and March. Urinary $\mathbf{N}$ concentrations ranged from $0.90 \%$ in August to $1.48 \%$ in January, higher than reported elsewhere (Doak 1952). Percentage of total urinary $N$ in the form of urea varied with season, with 67 and $30 \%$ being the maximum and minimum in June and March, respectively. Total urinary $\mathbf{N}$ and urea- $\mathbf{N}$ concentrations were linearly correlated $\left(r^{2}=.96\right)$. More importantly, total urinary $\mathrm{N}$ and urea-N were linearly related to $\mathrm{N}$ concentration $\left(r^{2}=.76\right.$ and .75 , respectively) and to DM digestibility $\left(r^{2}=.71\right.$ and .67$)$ of the diet.
Fecal nitrogen concentration varied seasonally but with less amplitude than urinary $\mathbf{N}$ excretion. The highest fecal $\mathbf{N}$ concentration occurred in June and the lowest in January. Holechek et al. (1982) measured a similar range (1.53 to $3.41 \%$ ) for cattle grazing grassland and forested range in Oregon. Fecal $\mathbf{N}$ excretion per MBW, however, was several months out of phase with urinary $\mathbf{N}$ output, peaking in October (Table 2). High fecal $\mathrm{N}$ concentration in June may have resulted from highly digestible, high $\mathbf{N}$ forage. Late in the growing season, fecal $\mathrm{N}$ excretion apparently followed DMI (Table 1).

Estimates of $\mathrm{N}$ retention determined by the difference and by the LWG method were poorly correlated $(r=.30)$. Difference determinations suggested that experimental animals retained little $\mathbf{N}$, when in fact animals grew normally. The discrepancy may have been a result of cumulative errors in measurement of $\mathbf{N}$ flows. Alternately, animals may have been under sufficient stress that little $\mathbf{N}$ was retained during the 8-day trials; in this scenario, compensatory gains would have been made during the interim periods. Use of the LWG method indicated that $2.3 \mathrm{~kg} \mathrm{~N}$ was stored during the growing season (May through October), approximately $16 \%$ of the $\mathrm{N}$ ingested during this period. The remainder was excreted in urine and feces. Nitrogen retention in the dormant season (November through March) was negligible. Cattle were in positive $\mathbf{N}$ balance in November but lost $\mathbf{N}$ through the rest of the dormant season. Over the course of the study, an average of $8 \%$ of total ingested $\mathrm{N}$ was retained in cattle tissues.

\section{Energy Budget of Cattle}

Seasonal trends in gross energy intake paralleled those of DMI (Table 3). Gross energy intake per MBW was greatest in September and October. Throughout the growing season energy intake was above maintenance requirement (Fig. 1). Despite supplementation, ME was below maintenance requirement during mid and late winter (January through March).

Urinary energy excretion was closely correlated to urinary $\mathbf{N}$ excretion $\left(r^{2}=.86\right)$, with the highest levels in June and the lowest in 


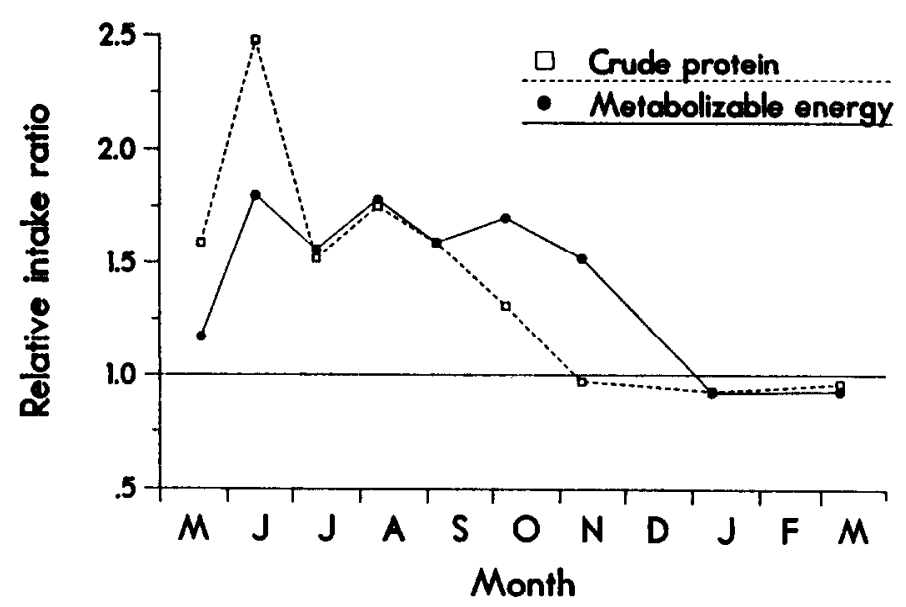

Fig. 1. Intake of crude protein and metabolizable energy relative to maintenance requirement (NRC 1984).

March. Seasonal trend in fecal energy excretion was a function of dry matter excretion, peaking in September. Fecal energy excretion remained relatively high throughout the dormant season.

Digestible energy (DE) intake was relatively high throughout the growing season, with apparent month-to-month fluctuations. Digestible energy intake per MBW declined steadily through the dormant season, the lowest level occurring in March. ME intake was higher than the free-ranging maintenance requirement (130-180 $\mathrm{kcal} / \mathrm{MBW}$ ) throughout the growing season but below maintenance in mid and late winter (Fig. 1). The free-ranging requirement estimated by Havstad and Malechek did not include added thermoregulatory costs of winter cold stress. Net energy for production ( $\mathrm{NE}_{\text {gnin }}$ after NRC 1984) was positive from May through November (Table 3).

\section{Nutritional Limits to Production}

Intake of crude protein $(\mathrm{N} \times 6.25)$ and intake of $\mathrm{ME}$ were each potentially limiting to cattle protection at different times of the year (Fig. 1). RCPI peaked early and steadily declined through the growing season. During winter RCPI was kept near maintenance requirements by supplementation. RMEI was above maintenance level throughout the growing season and did not decline through late summer and fall. Intake of ME was potentially more limiting early in the growing season and intake of crude protein was potentially limiting late in the growing season (Fig. 1). RCPI and RMEI were about equal in mid growing season and in the dormant season.

The fact that relative intake of a nutrient was lower than that of another did not necessarily indicate that that nutrient constrained growth. To test nutritional limitation, the relationship between
LWG and relative nutrient intake was examined. Heifer RLWG was strongly correlated $(r=.824)$ with RCPI (Fig. 2a), but weakly correlated $(r=.557)$ with RMEI(Fig. 2b). Relatively weak correlations between RLWG and relative intake of single nutrients may have indicated that different nutrients actually were limiting at different times. This was tested by examining the relationship between RLWG rate and the lesser of the 2 relative intake ratios. With the exception of the August sampling date, RLWG was highly correlated $(r=.987)$ with intake of the more limiting nutrient (Fig. 2c). Growth in August may have been influenced by other factors such as thermal stress. These results suggest that energy and crude protein intake limited cattle production on shortgrass range, but the identity of the limiting nutrient changed seasonally. Because maintenance levels are specific to classes of livestock, patterns of nutrient limitation may differ for other classes such as mature or lactating cows.

\section{Literature Cited}

Cordova, F.J., J.D. Wallace, and R.D. Pieper. 1978. Forage intake by grazing livestock: a review. J. Range Manage. 31:430-438.

Dean, R.E., J.E. Ellis, R.W. Rice, and R.E. Bement. 1975. Nutrient removal by cattle from a shortgrass prairie. J. Appl. Ecol. 12:25-29.

Doak, B.W. 1952. Some chemical changes in the nitrogenous constituents of urine when voided on pasture. J. Agr. Sci. 42:162-171.

Havstad, K.M., and J.C. Malechek. 1982. Energy expenditure by heifers grazing crested wheatgrass of diminishing availability. J. Range Manage. 35:447-450.

Holechek, J.L., M. Vavra, and D. Arthur. 1982. Relationships between performance, intake, diet nutritive quality and fecal nutritive quality of cattle on mountain range. J. Range Manage. 35:741-744.

Johnson, D.E., L.R. Rittenhouse, and M.M. Borman. 1982. Estimating rate of fecal or urine excretion with missing or incomplete collection. Proc., West. Sec. Amer. Soc. Anim. Sci. 33:287-288.

National Research Council. 1984. Nutrient requirements of domestic animals. No. 4. Nutrient Requirements of Beef Cattle. 6th revised edition. National Academy Press, Washington, D.C.

Rittenhouse, L.R., D.C. Clanton, and C.L. Streeter. 1970. Intake and digestibility of winter range forage by cattle with and without supplements. J. Anim. Sci. 31:1215-1221.

Senft, R.L, and L.R. Rittenhouse. 1985. A model of thermal acclimation in cattle. J. Anim. Sci. 61:297-306.

Senft, R.L., L.R. Rittenhouse, and M.A. Stillwell. 1984. Diets selected by cattle from plant communities on shortgrass range. Proc., West. Sec. Amer. Soc. Anim. Sci. 35:180-183.

Senft, R.L., L.R. Rittenhouse, and R.G. Woodmansee. 1985. Factors influencing patterns of cattle grazing behavior on shortgrass steppe. $J$. Range Manage. 38:82-87.

Stillwell, M.A., R.L. Senft, and L.R. Rittenhouse. 1983. Total urine collection from free-grazing heifers. J. Range Manage. 36:801-803.

Stillwell, M.A., and R.G. Woodmansee. 1981. Chemical transformation of urea nit rogen and movement of nitrogen in a shortgrass prairie soil. Soil Sci. Soc. Amer. J. 45:893-898.

Tilley, J.M.A., and R.A. Terry. 1963. A two stage technique for the in vitro digestion of forages. J. Brit. Grassl. Soc. 18:104-109.

Van Soest, P.J. 1982. Nutritional ecology of the ruminant. O \& B Books, Inc., Corvallis, Ore.
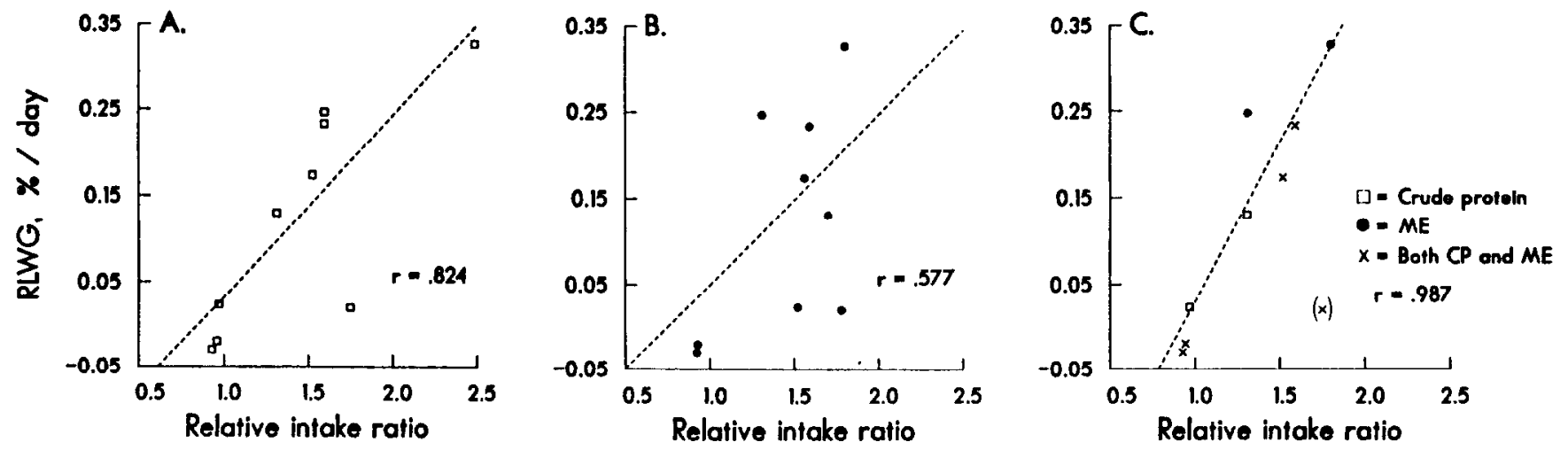

Fig. 2. Relationship between cattle relative lightweight gain (RLWG) and nutrient intake relative to maintenance requirement (NRC 1984). A. Crude protein. B. Metabolizable energy. C. The more limiting nutrient. The August sampling point is in parentheses. 